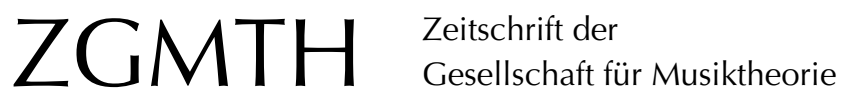

London, Justin (2003/05): Recent Rhythmic Research in North American Music Theory. ZGMTH 1-2/2/2-3, 163-168. https://doi.org/10.31751/522

(C) 2003/05 Justin London

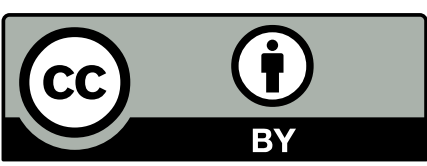

Dieser Text erscheint im Open Access und ist lizenziert unter einer Creative Commons Namensnennung 4.0 International Lizenz.

This is an open access article licensed under a

Creative Commons Attribution 4.0 International License.

veröffentlicht / first published: 01/04/2005

zuletzt geändert / last updated: 15/01/2010 


\title{
Recent Rhythmic Research in North American Music Theory
}

\author{
Justin London
}

As noted in London (2001), much current work in rhythmic theory and analysis can be traced back to Lerdahl and Jackendoff's A Generative Theory of Tonal Music (also known as "GTTM", 1983) and / or Carl Schachter's three important articles on rhythm and meter in The Music Forum (1976, 1980, 1987). While this is still largely true, several new areas of rhythmic interest have emerged. As is so often the case, these new areas follow the broader trends of current music-theoretic research. Thus, we find rhythmic theory and analysis: (a) allied to Neo-Riemannian theory, as well as other formal (i.e., computational) models, (b) directed to the analysis of non-western and popular music, (c) featured in various studies of the "history of theory", and (d) prominent in various analytical studies, especially with respect to the music of Bartók, Stravinsky, and minimalist composers. Lastly, some recent work, most notably Hasty (1997), draws on philosophical discussions of time and temporality in framing its approach to musical rhythm.

It goes without saying that many works occupy more than one category of rhythmic theory or analysis. Thus, for example, Temperly (2001), while grounded on the GTTM model, also examines popular and non-western musics, musical style and musical schemata, and analyzes a broad range of Western art music. Below I will briefly list contributions in each of these areas; readers interested in more details on each may find abstracts readily available, for the most part, in online sources such as RILM and Dissertation Abstracts Online. I have focused on work published in mainstream English-language music theory journals in the last decade; a more comprehensive survey would also include journals in psychology, computer music, new music / composition, ethnomusicology, aesthetics, and so forth. Overviews of earlier research may be found in London (2001, 2002).

\section{Extensions of the GTTM Rhythmic Models}

First and foremost here is Lerdahl's own Tonal Pitch Space (2001). While mainly interested in aspects of tonal prolongation - the "stability conditions" for tonal relationships - this volume also includes further thoughts on rhythm and meter. Temperly (2001) develops a computational model for various aspects of GTTM's (as well as his own) preference rules, including those for rhythm and meter. Several recent dissertations explore other 
aspects of the GTTM project, including Dodson (2002) on hypermetric transformation, Margulis (2003) on melodic expectation, and Ito (2004) on impulse structure. London (2004) is also heavily indebted to the metric well-formedness rules laid out in GTTM.

\section{Rhythm in Schenkerian Theory and Analysis}

Schachter himself has not been idle since his last Music Forum publication; his "The Triad as Place and Action" (1995) contains additional observations on rhythm and rhythmic conflict. Likewise many of the discussions of metric "dissonance" noted below have strong affinities with Schenkerian tonal analysis. Willner (1999, 2005) has explored phrase rhythm in Baroque music, especially the music of Händel, while Samarotto (1999a, 1999b) has dealt with rhythmic irregularity and "temporal plasticity", especially in the music of Beethoven, and both theorists work within a broader Schenkerian framework for formal and tonal structure.

\section{Neo-Riemannian Theory, Formal Models}

Richard Cohn's work has been at the epicenter of the "Neo-Riemannian School" of music theorists. While Neo-Riemannians have been mainly concerned with harmonic and tonal theory, Cohn (2001) uses "ski hill diagrams" to look at the relationships between metric levels, a temporal analog or "zeitnetz" to the "tonnetz" representations of tonal relationships. Formalized accounts of duration have been posited by Agmon (1997) and Pearsall (1995), while Roeder (1995) proposes a formalized "calculus of accent".

\section{Perception and Cognition}

A concern with the psychological aspects of rhythm and meter can be found in many recent studies, as much of work following the GTTM model involves empirical research as a primary or secondary source, as does Hasty (1997). Epstein (1995) is a wide-ranging and highly speculative study of the neurobiological bases for our sense of tempo and tempo preferences. London (2004) explicitly incorporates empirical research in its definitions of metric well-formedness; it also contains many references to recent research in rhythmic perception and cognition.

\section{History of Music Theory}

A number of theorists have addressed historical aspects of rhythm and meter, that is, either (a) the theory and analysis of rhythm in pre-tonal music, or (b) the work of theorists who address the rhythm of common-practice period music prior to the 20th century. In the former category, Boone $(1999,2000)$ has explored mensural time and text-music relationships in Dufay, while Maw (2004) examines meter in Machaut. In the latter 
category, Arlin (2000) looks at Fétis's theories of meter and metric change, while Dogantan (1997) considers Lussy's account of musical expression.

\section{Theory and Analysis of Popular and Non-Western Music}

One of the most rapidly growing areas of rhythmic theory and analysis involves examination of musical repertoire beyond the canon of Western art music. Agawu (1987, 1995, 2003) has urged for serious consideration of non-western rhythm using all of the analytical tools available, and this has been taken up by McLachlan (2000) and Temperly $(2000,2001)$, with respect to the metric structure of North African Music, as well as Clayton (2000), with respect to the North Indian Raga. Similarly, Butler (2001, 2003) and Hughes (2003) have given careful scrutiny to the rhythmic and metric structure of electronic dance music and the music of Stevie Wonder, respectively.

\section{Metric Dissonance and other Analytical Projects}

Much attention has been paid in recent years to the notion of metric "dissonance," Krebs in his Fantasy Pieces (1999) - an examination of metric conflict and dissonance in Schumann - which is an extension of his seminal paper on metric dissonance (Krebs 1987). Krebs's work has inspired Grave's (1995) exploration of metric dissonance in Haydn, analyses by Leong (1999) and Roeder (2001) of Bartók, Smith (2001) on metrical displacement in Brahms, and Malin's recent (2003) dissertation on metric dissonance in the German lied. Rhythmic aspects of twentieth-century music, especially where there is a highly saturated rhythmic / metric texture, has also received attention, as in Horlacher's studies of Bartók and Stravinsky (2001a, 2001b), Callender (2001) on Nancarrow, and Roeder on Reich and Torke (2003a, 2003b).

\section{Temporal Theory}

Hasty's Meter as Rhythm (1997) is a broad ranging study that encompasses the history of rhythmic and metric theory, research in music perception, and post-tonal meter. Its central topic, though, is a theory of meter as temporal process. Antecedents to Hasty's work include Lochhead (1989-90) and Kramer (1988). Morris (2002) is a reply to Hasty. 


\section{Bibliography}

Agawu, V. Kofi. 1987. "The Rhythmic Structure of West African Music." The Journal of Musicology 5: 400-418.

— 1995. African Rhythm: A Northern Ewe Perspective. Cambridge: Cambridge University Press.

—. 2003. Representing African Music: Postcolonial Notes, Queries, Positions. New York: Routledge.

Agmon, Eyton. 1997. "Musical Durations as Mathematical Intervals: Some Implications for the Theory and Analysis of Rhythm." Music Analysis 16: 45-75.

Arlin, Mary. 2000. "Metric Mutation and Modulation: The Nineteenth-Century Speculations of F.-J. Fétis." The Journal of Music Theory 44: 261-322.

Boone, Graeme M. 1999. Patterns in Play: A Model for Text Setting in the Early French Songs of Guillaume Dufay. Lincoln: University of Nebraska Press.

—. 2000. "Marking Mensural Time." Music Theory Spectrum 22: 1-43.

Butler, Mark J. 2001. "Turning the Beat Around: Reinterpretation, Metrical Dissonance, and Asymmetry in Electronic Dance Music." Music Theory Online 7. http://www. societymusictheory.org:16080/mto/issues/issues.html.

—. 2003. "Unlocking the Groove: Rhythm, Meter and Musical Design in Electronic Dance Music." Ph.D. Diss., Indiana University.

Callender, Clifton. 2001. "Formalized accelerando: An Extension of Rhythmic Techniques in Nancarrow's Acceleration Canons." Perspectives of New Music 39: 188-210.

Clayton, Martin. 2000. Time in Indian Music: Rhythm, Metre, and Form in North Indian Rag Performance. New York: Oxford University Press.

Cohn, Richard L. 2001. "Complex Hemiolas, Ski-Hill Graphs and Metric Spaces." Music Analysis 20: 295-326.

Dodson, Alan. 2002. "Performance and Hypermetric Transformation: An Extension of the Lerdahl-Jackendoff Theory." Music Theory Online 8. http://www.societymusictheory.org:16080/mto/issues/issues.html.

Dogantan, Mine. 1997. "Mathis Lussy's Theory of Rhythm as a Basis for Musical Expression." Ph.D. Diss., Columbia University.

Epstein, David. 1995. Shaping Time: Music, the Brain, and Performance. New York: Schirmer.

Grave, Floyd. 1995. "Metrical Dissonance in Haydn." The Journal of Musicology 12: $168-202$.

Hasty, Christopher. 1997. Meter as Rhythm. Oxford: Oxford University Press.

Horlacher, Gretchen. 2001a. "Bartók's Change of Time: Coming Unfixed." Music Theory Online 7. http://www.societymusictheory.org:16080/mto/issues/issues.html.

—. 2001b. "Running in Place: Sketches and Superimposition in Stravinsky's Music." Music Theory Spectrum 23: 196-216. 
Hughes, Tim. 2003. The Ever-Changing Same: Repetition, Grooves, and Flow in the Music of Stevie Wonder. Ph.D. Diss., University of Washington.

Ito, John P. 2004. Impulse Structure in Tonal Music: A Theory of the Metrical Coordination of Motor Behavior in Performers. Ph.D. Diss., Columbia University.

Kramer, Jonathan D. 1988. The Time of Music. New York: Schirmer.

Krebs, Harald. 1987. "Some Extensions of the Concepts of Metrical Consonance and Dissonance." Journal of Music Theory 31: 99-120.

—. 1999. Fantasy Pieces: Metrical Dissonance in the Music of Robert Schumann. New York: Oxford University Press.

Leong, Daphne. 1999. "Metric Conflict in the First Movement of Bartók's Sonata for Two Pianos and Percussion." Theory and Practice 24: 67-90.

Lerdahl, Fred and Ray Jackendoff. 1983. A Generative Theory of Tonal Music. Cambridge: MIT Press.

Lerdahl, Fred. 2001. Tonal Pitch Space. Oxford: Oxford University Press.

Lochhead, Judy. 1989-1990. "The Metaphor of Musical Motion: Is There an Alternative?" Theory and Practice 14-15: 83-104.

London, Justin. 2001. "Rhythm." In The New Grove Dictionary of Music and Musicians, revised edition, ed. J. Tyrrell and S. Sadie, Vol. 21. Oxford University Press: 277309.

—. 2002. "Musical Time in 20th-Century Theory." In The Cambridge History of Western Music Theory, ed. T. Christensen. Cambridge: Cambridge University Press, 695725 .

- 2004. Hearing in Time. Oxford: Oxford University Press.

Malin, Yonatan. 2003. Metric Dissonance and Music-Text Relations in the German Lied. Ph.D. Diss., University of Chicago.

Margulis, Elizabeth Hellmuth. 2003. Melodic Expectation: A Discussion and Model. Ph.D. Diss., Columbia University.

Maw, David. 2004. "Trespasser Measure: Meter in Machaut's Polyphonic Songs." The Journal of Musicology 21: 46-126.

McLachlan, Neil. 2000. "A Spatial Theory of Rhythmic Resolution." Leonardo 10: 6167.

Morris, Robert D. 2002. "A Footnote to Hasty, Whitehead, and Plato: More Thoughts on Stefan Wolpe's Music." Perspectives of New Music 40: 183-188.

Pearsall, Edward R. 1997. "Interpreting Music Durationally: A Set-Theory Approach to Rhythm." Perspectives of New Music 35: 205-230.

Roeder, John. 1995. "A Calculus of Accent." Journal of Music Theory 39: 1-46.

- 2001. "Pulse Streams and Problems of Grouping and Metrical Dissonance in Bartók's With Drums and Pipes." Music Theory Online 7. http://www.societymusictheory.org:16080/mto/issues/issues.html. 
—. 2003a. "Beat-Class Modulation in Steve Reich's Music." Music Theory Spectrum 25: $275-304$.

- 2003b. "The Craft of Hybrid Composition: Meter, Tonality, and Grouping in Michael Torke's Adjustable Wrench." Perspectives of New Music 41: 122-158.

Samarotto, Frank. 1999a. A theory of Temporal Plasticity in Tonal Music: An Extension of the Schenkerian Approach to Rhythm with Special Reference to Beethoven's Late Music. Ph.D. Diss., City University of New York.

—. 1999b. "Strange Dimensions: Regularity and Irregularity in Deep Levels of Rhythmic Reductions." In Schenker Studies 2. ed. C. Schachter and H. Siegel. Cambridge: Cambridge University Press, 222-38.

Schachter, Carl. 1995. "The Triad as Place and Action." Music Theory Spectrum 17: 149-169.

- 1976. "Rhythm and Linear Analysis: A Preliminary Study." In The Music Forum vol. 4, ed. F. Salzer and C. Schachter. New York: Columbia University Press, 281-334.

—. 1980. "Rhythm and Linear Analysis: Durational Reduction." In The Music Forum vol. 5, ed. F. Salzer and C. Schachter. New York: Columbia University Press, 197232.

- 1987. "Rhythm and Linear Analysis: Aspects of Meter." In The Music Forum vol. 6.1, ed. F. Salzer and C. Schachter. New York: Columbia University Press, 1-59.

Smith, Peter H. 2001. "Brahms and the Shifting Barline: Metric Displacement and Formal Process in the Trios with Wind Instruments." Brahms Studies 3: 191-229.

Temperly, David. 2000. "Meter and Grouping in African Music: A View from Music Theory." Ethnomusicology 44: 65-96.

- 2001. The Cognition of Basic Musical Structures. Cambridge, MA: MIT Press.

Willner, Channan. 1999. "Sequential Expansion and Handelian Phrase Rhythm." In Schenker Studies 2, ed. C. Schachter and H. Siegel. Cambridge: Cambridge University Press, 192-221.

—. 2005. Durational Pacing in Händel's Instrumental Works: The Nature of Temporality in the Music of the High Baroque. Ph.D. Diss., The City University of New York. 